\title{
HUBUNGAN ANTARA PARENTING STRESS DENGAN STRATEGI REGULASI EMOSI ORANG TUA YANG MEMILIKI ANAK USIA SEKOLAH DASAR (MIDDLE CHILDHOOD) DI JABODETABEK
}

\author{
Srifianti \\ Fakultas Psikologi Universitas Esa Unggul \\ Jalan Arjuna Utara No.9 Tol Tomang Kebon Jeruk, Jakarta Barat - 11510 \\ srifianti@esaunggul.ac.id
}

\begin{abstract}
Violence in children increased from 1,975 cases in 2015 to 6,820 cases in 2016. This shows that the psychological condition of parents can affect their behavior in parenting and greatly affect children's development. Parents who have children who are at a critical development stage, namely the age of elementary school (Middle Childhood), where this is the child's first school experience and various demands for developmental tasks and school work begin, which will be a stressor for parents. If parents cannot manage their emotions, it will be associated with higher parental stress levels. The purpose of this study is to analyze the relationship between parenting stress and the emotional regulation strategy of parents who have elementary school age children (Middle Childhood) in the Greater Jakarta area. The population and sample in this study were parents who had 241 elementary school aged children (Middle Childhood). The parenting stress measuring instrument used is the one developed by Berry and Jones (1995) with a total of 18 items and after being tested into 16 items with a reliability value of 0.87. Meanwhile, a measuring tool for measuring emotional regulation was developed by Gross and John (2003) with a total of 10 items. The reliability value was 0.75 for the cognitive response aspect and 0.71 for the expressive suppression aspect. The research method used is a descriptive quantitative study with correlation al methods, and using the correlation analysis test from Charles Spearman. The results of the statistical test were -0.200 with a significance level of 0.01 , which means that there is a negative relationship between parenting stress and the emotional regulation strategy of parents who have elementary school age children (Middle Childhood) in Jabodetabek.
\end{abstract}

Keywords: parenting stress, emotion regulation, middle childhood

\begin{abstract}
Abstrak
Kekerasan pada anak meningkat dari 1.975 kasus tahun 2015 menjadi 6.820 kasus pada tahun 2016. Ini menunjukkan kondisi psikologis orang tua dapat memengaruhi perilakunya dalam pengasuhan dan sangat memengaruhi perkembangan anak. Orang tua yang memiliki anak yang berada pada tahapan perkembangan kritis yakni usia Sekolah Dasar (Middle Childhood) dimana ini merupakan pengalaman pertama sekolah anak dan berbagai tuntutan tugas perkembangan dan tugas sekolah dimulai, yang akan menjadi stressor bagi orang tua. Apabila orang tua tidak dapat mengatur emosinya akan berkaitan dengan tingkat stres orang tua yang lebih tinggi. Tujuan dari penelitian ini yaitu menganalisis hubungan parenting stress dengan strategi regulasi emosi orang tua yang memiliki anak usia Sekolah Dasar (Middle Childhood) di kawasan Jabodetabek. Populasi dan sampel dalam penelitian ini adalah orang tua yang memiliki anak Usia Sekolah Dasar (Middle Childhood) yang berjumlah 241 orang. Alat ukur parenting stress yang digunakan adalah yang dikembangkan oleh Berry dan Jones (1995) dengan jumlah 18 aitem dan setelah diuji coba men jadi 16 item dengan nilai reliabilitas sebesar 0,87 . Sedangkan alat ukur untuk mengukur regulasi emosi dikembangkan oleh Gross dan John (2003) dengan jumlah 10 aitem. Didapatkan nilai reliabilitas sebesar 0,75 untuk aspek Cognitive Reappraissal dan 0,71 untuk aspek Expressive Suppression. Metode penelitian yang dilakukan adalah studi deskriptif kuantitatif dengan metode korelasional, dan menggunakan uji analisis korelasi dari Charles Spearman. Hasil uji statistik diperoleh hasil 0,200 dengan taraf signifikansi 0,01 yang berarti terdapat hubungan negatif antara parenting stress dengan strategi regulasi emosi orang tua yang memiliki anak usia Sekolah Dasar (Middle Childhood) di Jabodetabek.
\end{abstract}

Kata Kunci : tekanan pengasuhan, regulasi emosi, fase usia sekolah dasar 


\section{Pendahuluan}

Tantangan pengasuhan yang dihadapi oleh orang tua akan bertambah seiring dengan bertambahnya usia anak, salah satunya yaitu ketika anak memasuki tahapan perkembangan middle childhood atau yang biasa disebut usia sekolah dasar. Pada tahapan usia sekolah dasar yakni tahap perkembangan middle childhood merupakan salah satu tahap perkembangan krusial yang terkadang tidak diperhatikan dalam tahap perkembangan manusia (Del Giudice, 2014).

Ketika anak berada di tahap usia Sekolah Dasar, orang tua memiliki beban tambahan dan tanggung jawab tambahan, karena jejaring sosial anak berkembang secara signifikan selama masa ini (Bornstein, 2002). Di masa ini interaksi anak tidak terbatas hanya pada anggota keluarga atau orangorang yang mengunjungi rumahnya lagi. Seiring dengan interaksi anak yang semakin luas dengan lingkungannya, orang tua perlu melakukan usaha lebih dalam melakukan pengawasan terhadap anak mereka. Apabila orang tua tidak dapat melakukan pengawasan dan pengasuhan yang baik pada tahapan ini maka akan muncul perilaku-perilaku kekerasan pada anak.

Pusat Informasi Kementrian Kesehatan Indonesia (dalam Mardina, 2018) melaporkan hasil penelitian UNICEF pada tahun 2015 yang menyatakan $40 \%$ anak pernah mengalami kekerasan secara fisik dalam rangka pemberian disiplin. Dikutip dalam suatu artikel, Presiden Joko Widodo juga pernah mengungkapkan kenaikan angka kekerasan pada anak, yang pada tahun 2015 dilaporkan berjumlah 1.975 meningkat menjadi 6.820 kasus di tahun 2016 (Pinandita, 2020). Data ini menunjukan bahwa tingginya tingkat stress yang terjadi pada orang tua sehingga mereka dapat melakukan kekerasan secara fisik misalnya dalam rangka pemberian disiplin kepada anaknya.

Tingginya tingkat stress dapat disebabkan oleh kurangnya kemampuan yang dimiliki orangtua dalam mengenali, menilai, mengatur, dan mengevaluasi emosi yang dimiliki sehingga emosiemosi yang dirasakan tidak dapat ditampilkan pada situasi yang tepat. Kemampuan ini dinamakan regulasi emosi. Regulasi emosi juga dapat dikatakan sebagai strategi yang digunakan oleh individu secara sadar untuk mengatur respon emosi individu dalam menghadapi suatu kejadian (Gross \& Thompson, 2007).

Dalam menggunakan kemampuan ini terdapat dua strategi yang biasa digunakan yakni strategi cognitive reappraisal dan expressive suppression. Terdapat perbedaan individual yang terjadi kepada seseorang yang menggunakan strategi cognitive reappraisal dan orang yang menggunakan strategi expressive suppression. Orang yang menggunakan strategi regulasi emosi cognitive reappraisal mengungkapkan emosi positif yang lebih besar dan emosi negatif yang lebih kecil, sedangkan orang yang menggunakan strategi regulasi emosi expressive suppression mengungkapkan emosi positif yang lebih sedikit dan emosi negatif yang lebih besar (Gross \& John, 2003). Ada beberapa faktor yang mempengaruhi regulasi emosi individu yaitu faktor lingkungan, faktor pengalaman, pola asuh orang tua, jenis kelamin.

Pada penelitian ini ingin melibatkan salah satu faktor yang memengaruhi regulasi emosi orang tua yaitu faktor yang berkaitan dengan pola asuh orang tua. Kondisi yang pada umumnya dialami oleh orang tua khususnya di dalam pengasuhan yaitu stres yang merupakan reaksi terhadap lingkungan pada terjadinya kehilangan atau kerugian (Berry \& Jones, 1995). Sementara stress di dalam pengasuhan sering disebut parenting stress. Parenting stress secara spesifik didefinisikan sebagai serangkaian proses yang mengarah pada reaksi psikologis dan fisiologis yang tidak menyenangkan yang timbul dari adanya upaya untuk beradaptasi dengan tuntutan sebagai orang tua (Deater-Deckard, 2004).

Komponen parenting stress menurut Berry dan Jones (1995) meliputi komponen positif (pleasure), di dalam parenting stress menimbulkan keuntungan bagi orang tua yaitu secara emosional dan pengembangan diri. Selanjutnya komponen negatif (strain) melibatkan adanya tuntutan terhadap berbagai sumber yaitu biaya, waktu, tenaga serta adanya larangan, perasaan malu dan kontrol terhadap hal tersebut.

Berbagai penelitian mengenai tema parenting banyak dilakukan terutama penelitian yang mengukur mengenai tingkat stres pengasuhan pada orang tua yang memiliki anak dengan masalah perkembangan merupakan proses yang penuh stress bagi orang tua karena seringkali tingkat pengasuhannya lebih sulit dan intensif dibandingkan mengasuh anak dengan perkembangan normal (Small, 2010). Beberapa penelitian menemukan adanya kaitan antara regulasi emosi dengan stres di dalam pengasuhan. Hanya saja penelitian tersebut lebih banyak secara spesifik dilakukan pada orang tua yang memiliki anak kebutuhan khusus yang terdapat hubungan negatif antara regulasi emosi dengan stress pengasuhan pada ibu yag memiliki anak cerebral palsy (Ikasari \& Kristiana, 2018). Pada penelitian lain tampak hasil regulasi emosi berpengaruh pada perilaku pengasuhan orang tua melalui parenting stress pada orang tua yang 
memiliki anak Autism (Hu et al., 2019). Hal ini menunjukan bahwa ada kaitan antara parenting stress dengan regulasi emosi khususnya pada orang tua yang memiliki anak kebutuhan khusus.

Hal ini berbeda dengan orang tua yang memiliki anak dengan perkembangan yang normal akan tetapi berada pada tahapan perkembangan yang kritis yakni usia Sekolah Dasar (Middle Childhood), yang pada usia ini merupakan pengalaman pertama sekolah pada anak yang menentukan kesuksesan atau kegagalan di masa depan (Papalia et al., 2004). Tentunya hal ini akan menjadi stressor bagi orang tua. Apabila orang tua tidak dapat mengatur emosi yang dirasakan maka akan berkaitan dengan tingkat stres orang tua yang lebih tinggi dan penggunaan strategi regulasi emosi akan berpengaruh terhadap proses pengasuhan anak.

Berdasarkan fenomena di atas, peneliti tertarik untuk mengetahui hubungan antara stress pengasuhan yang dialami orang tua (parenting stress) dengan strategi regulasi emosi orang tua yang memiliki anak Usia Sekolah Dasar (Middle Childhood). Bagaimana Strategi Regulasi emosi ketika orang tua mengalami stres di dalam pengasuhan? Penelitian ini ingin mengeksplorasi bagaimana kedua variabel ini saling berkaitan. Dengan demikian, hipotesis yang peneliti ajukan pada penelitian ini adalah terdapat hubungan antara parenting stress dengan strategi regulasi emosi orang tua yang memiliki anak usia Sekolah Dasar (Middle Childhood) di daerah Jabodetabek.

\section{Metode Penelitian}

Metode penelitian yang digunakan dalam penelitian ini adalah analisis deskriptif kuantitatif yaitu dengan pedoman statistik nonparametric menggunakan program statistic computer SPSS Version 23.

Analisis deskriptif nonparametrik Uji Korelasi dari Charles Spearman digunakan untuk melihat hubungan antara parenting stress dengan regulasi emosi orang tua yang memiliki anak usia Sekolah Dasar (Middle Childhood) di Jabodetabek. Teknik pengumpulan data yang dipakai dalam penelitian ini adalah berupa Kuesioner, yaitu melalui skala Parental Stress Scale (PSS) yang dikembangkan oleh Berry \& Jones (1995) dan Kuesioner untuk mengukur Regulasi Emosi dikembangkan oleh Gross dan John (2003).

Dalam penelitian ini, peneliti pada awalnya mendapatkan total 303 responden, 86 responden didapatkan melalui pengambilan data secara langsung (offline), 217 responden didapatkan melalui pengambilan data secara daring (online) melalui google form. Hal ini dikarenakan pengambilan data secara langsung tidak dimungkinkan karena terkendala masa pandemi covid-19. Kemudian dari 303 responden terdapat responden yang tidak sesuai dengan karakteristik yang telah ditetapkan sebelumnya seperti usia anak, lokasi tempat tinggal diluar Jabodetabek sehingga sebanyak 62 orang tidak diikutkan dalam penelitian. Dengan demikian, setelah dikurangi responden outlier, jumlah responden yang terlibat dalam penelitian ini menjadi sebanyak 241 responden/orang tua. Adapun karakteristik responden penelitian ini dapat digambarkan sebagai berikut :

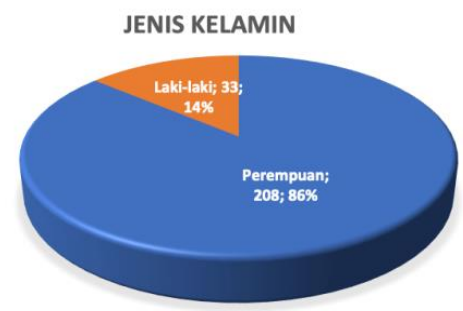

USIA
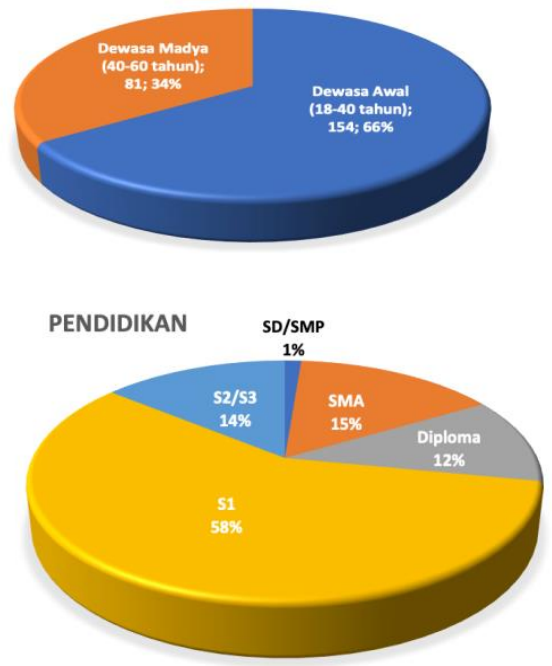

JENIS PEKERJAAN

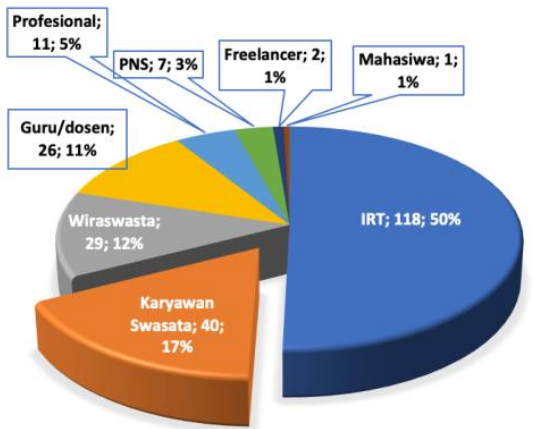




\section{Hasil dan Pembahasan}

Secara garis besar diketahui $54 \%$ dari partisipan memiliki regulasi emosi yang sedang, sedangkan $46 \%$ partisipan memiliki regulasi emosi yang tinggi. Artinya secara umum orang tua yang tinggal di Jabodetabek yang termasuk dalam partisipan ini mampu meregulasi emosinya dengan tepat. Sementara, $93 \%$ partisipan memiliki parenting stress yang rendah dan hanya $8 \%$ yang memiliki parenting stress yang sedang. Dengan demikian dapat diartikan bahwa sebagian besar orang tua di Jabodetabek yang memiliki anak usia Sekolah Dasar memiliki parenting stress yang rendah.

Hasil Perhitungan Statis tik Hubungan antara Parenting Stress dengan Regulasi Emosi Orang Tua yang Memiliki Anak Usia Sekolah Dasar (Middle Childhood)

Tabel 1

Hubungan antara Parenting Stress dengan Strategi Regulasi emosi

\begin{tabular}{lcr}
\hline \multicolumn{1}{c}{ Variabel } & PS & \multicolumn{1}{c}{ RE } \\
\hline PS Pearson Correlation & 1 & $-0,200 * *$ \\
Sig. (2-tailed) N & 241 & 0,002 \\
& $-0,200 * *$ & 241 \\
RE Pearson & 0,002 & 1 \\
Correlation Sig. (2-tailed) & 241 & 241 \\
N & \\
\hline$* *$ Correlation is significant at $p<0,01$ (2-tailed)
\end{tabular}

Berdasarkan tabel tersebut, diketahui bahwa antara parenting stress dengan strategi regulasi emosi memiliki hubungan dengan koefisien korelasi sebesar $-0,20$ dengan nilai signifikansi 0,01 . Hal ini menunjukkan adanya hubungan yang negatif antara parenting stress dengan strategi regulasi emosi. Semakin tinggi parenting stress orang tua, maka semakin rendah strategi regulasi emosi yang dimiliki orang tua yang memiliki anak usia Sekolah Dasar (Middle Childhood). Semakin tinggi tingkat stress yang dipersepsikan oleh orang tua, semakin buruk atau semakin kurang strategi regulasi emosi yang digunakan oleh orang tua yang memiliki anak usia Sekolah Dasar.

Kemudian analisis tambahan dilakukan untuk melihat hubungan antara parenting stress dengan aspek-aspek yang ada pada strategi regulasi emosi yakni strategi cognitive reappraisal dan strategi expressive suppression. Analisis tambahan dilakukan untuk menguji dua hipotesis lainnya yaitu dengan menggunakan uji korelasi Spearman. Hasil analisis tambahan dapat dilihat dalam Tabel 2 . sebagai berikut :
Tabel 2

Hubungan antara Parenting Stress dengan Strategi Regulasi Emosi Cognitive Reappraisal

\begin{tabular}{lrr}
\hline Variabel & PS & \multicolumn{2}{c}{ RECR } \\
\hline PS Pearson & 1 & $-0,205^{* *}$ \\
Correlation Sig. (2- & & 0,001 \\
tailed) N & 241 & 241 \\
& & \\
RECR Pearson & $-0,205^{* *}$ & 1 \\
Correlation & 0,001 & 241 \\
Sig. (2-tailed) N & 241 & \\
\hline
\end{tabular}

** Correlation is significant at $p<0,01$ (2-tailed)

Berdasarkan tabel tersebut, diketahui bahwa parenting stress dengan strategi regulasi emosi cognitive reappraisal memliki hubungan dengan koefisien korelasi sebesar -0,205 dengan nilai signifikansi 0,01. Hal ini menunjukkan hubungan negatif antara parenting stress dengan strategi regulasi emosi jenis cognitive reappraisal. Semakin tinggi parenting stress, maka semakin rendah strategi regulasi emosi pada aspek cognitive reappraisal yang dimiliki oleh orang tua yang memiliki anak usia Sekolah Dasar (Middle Childhood).

Hasil penelitian menunjukkan bahwa terdapat hubungan negatif antara parenting stress dengan strategi regulasi emosi cognitive reappraisal. Semakin tinggi parenting stress, maka semakin rendah strategi regulasi emosi pada aspek cognitive reappraisal yang dimiliki olah orang tua yang memiliki anak usia Sekolah Dasar (Middle Childhood). Hal ini menunjukkan bagaimana orang tua yang memiliki parenting stress tinggi memiliki aspek strategi regulasi emosi cognitive reappraisal yang rendah. Berdasarkan penjelasan Gross dan John (2003) mereka yang menggunakan strategi regulasi emosi cognitive reappraisal mengungkapkan emosi positif yang lebih besar dan emosi negatif yang lebih kecil, sedangkan orang yang menggunakan strategi regulasi emosi expressive suppression mengungkapkan emosi positif yang lebih sedikit dan emosi negatif yang lebih besar (Gross \& John, 2003). Dari uraian tersebut dapat dijelaskan bahwa orang tua yang memiliki tingkat stress yang tinggi sulit untuk melakukan cognitive reappraisal karena mereka sulit mengenali situasi - situasi sebelum kejadian. Perlu adanya pengenalan diri atau kesadaran bahwa dirinya sedang mengalami situasi yang penuh stress. 
Tabel 3

Hubungan antara Parenting Stress dengan Strategi Regulasi Emosi Expresive Suppression

\begin{tabular}{lrr}
\hline Variabel & PS & \multicolumn{2}{c}{ REES } \\
\hline PS Pearson & 1 & $-0,107$ \\
Correlation Sig. & & 0,097 \\
(2-tailed) N & 241 & 241 \\
\hline REES Pearson & $-0,107 * *$ & 1 \\
Correlation Sig. & 0,097 & \\
(2-tailed) N & 241 & 241 \\
\hline Correlation is significant at $p<0,01$ (2-tailed)
\end{tabular}

Berdasarkan tabel tersebut, diketahui bahwa korelasi antara parenting stress dengan strategi regulasi expressive suppression tidak signifikan dengan nilai korelasi sebesar $-0,107$ dan nilai signifikansi 0,097. Hal ini menunjukkan bahwa tidak terdapat hubungan antara parental stress mereka dengan penggunaan strategi expressive suppression dalam melakukan regulasi emosi pada orang tua yang menjadi subjek penelitian ini.

Hasil dalam tabel ini menunjukkan bahwa tidak terdapat hubungan antara parenting stress dengan aspek strategi regulasi expressive suppression. Dari lima kategori strategi dalam regulasi emosi yang ada, terdapat empat strategi yang termasuk dalam cognitive reappraisal dan hanya ada satu strategi yang termasuk dalam expressive suppression. Dengan korelasi umum antara parenting stress dan regulasi emosi yang tidak terlalu tinggi, bisa diasumsikan bahwa kemungkinan digunakannya strategi expressive suppression lebih kecil daripada digunakannya strategi cognitive reappraisal yang terdiri dari lebih banyak strategi.

Lebih jauh dalam penelitian oleh Moore, Zoellner, dan Mollenholt (2008) ditemukan mengenai hubungan antara expressive suppression dengan mereka yang memiliki tingkat stress yang cenderung tinggi, namun terdapat strategi rumination yang menjadi faktor penengah/perantara dalam prosesnya. Strategi rumination ini termasuk dalam cognitive reappraisal yaitu ketika seseorang melakukan perubahan arah perhatian mereka (attention deployment) terutama pada mereka yang mengalami Post Traumatic Stress Disorder, gangguan kecemasan, dan gejala depresi. Oleh karena itu, kemungkinan tidak ditemukan hubungan langsung dari parenting stress dengan penggunaan strategi expressive suppression pada orang tua yang menjadi subjek dalam penelitian ini. Selanjutnya, dalam penelitian yang sama, berdasarkan analisis faktor yang mereka lakukan, expressive suppression dan cognitive reappraisal ditemukan sebagai konstruk yang saling independen satu sama lain sehingga perubahan atau keadaan dari masingmasing strategi regulasi emosi tidak mengarah kepada perubahan strategi regulasi emosi lainnya. Independensi ini turut menjelaskan mengapa cognitive reappraisal memiliki hubungan dengan variabel parenting stress sedangkan expressive suppression tidak menunjukkan adanya hubungan yang signifikan dengan parenting stress.

\section{Simpulan}

Berdasarkan hasil penelitian dapat disimpulkan bahwa terdapat hubungan negatif antara parenting stress dengan strategi regulasi emosi orang tua yang memiliki anak usia Sekolah Dasar (Middle Childhood). Hal ini menunjukkan adanya hubungan yang negatif antara parenting stress dengan strategi regulasi emosi. Semakin tinggi parenting stress orang tua, maka semakin rendah strategi regulasi emosi yang dimiliki orang tua yang memiliki anak usia Sekolah Dasar (Middle Childhood). Semakin tinggi tingkat parenting stress yang dipersepsikan oleh orang tua, semakin buruk atau semakin kurang strategi regulasi emosi yang digunakan oleh orang tua yang memiliki anak usia Sekolah Dasar.

Kemudian diketahui lebih lanjut bahwa terdapat hubungan negatif antara parenting stress dengan strategi regulasi emosi cognitive reappraisal. Artinya semakin tinggi parenting stress, maka semakin rendah strategi regulasi emosi pada aspek cognitive reappraisal yang dimiliki olah orang tua yang memiliki anak usia Sekolah Dasar (Middle Childhood). Hal ini menunjukkan bagaimana orang tua yang memiliki parenting stress tinggi memiliki aspek strategi regulasi emosi cognitive reappraisal yang rendah. Dari uraian tersebut dapat dijelaskan bahwa orang tua yang memiliki tingkat stres yang tinggi sulit untuk melakukan cognitive reappraisal karena mereka sulit mengenali situasi-situasi sebelum kejadian. Perlu adanya pengenalan diri atau kesadaran bahwa dirinya sedang mengalami situasi yang penuh stress.

Kemudian mengenai gambaran tingkat parenting stress pada orang tua yang memiliki anak usia Sekolah Dasar (Middle Childhood) di Jabodetabek berada pada tingkat rendah dan sedang sehingga dapat diasumsikan bahwa kondisi parenting stress yang dihadapi orang tua dalam menghadapi anak usia Sekolah Dasar terbilang cukup baik. Hal ini dikarenakan walaupun di kota besar dengan sumber stress yang tinggi, namun orang tua dapat dengan mudah mendapatkan pengetahuan mengenai pemahaman dalam cara menangani stress misalnya dari kegiatan seminar parenting dan lain sebagainya. 
Begitupun dalam hal strategi regulasi emosi orangtua yang memiliki anak usia Sekolah Dasar (Middle Childhood) di Jabodetabek berada pada tingkat sedang dan tinggi. Sehingga hal ini menunjukkan cukupnya strategi regulasi emosi yang sudah diterapkan oleh orang tua dengan anak Sekolah Dasar yang menjadi responden penelitian ini. Hal ini dikarenakan orang tua di kota besar memiliki tingkat pendidikan pada taraf Sekolah Menengah ke atas sehingga memiliki pemahaman yang lebih baik terhadap situasi stress sehingga dapat menerapkan strategi regulasi emosi dengan baik.

Keterbatasan dalam penelitian ini adalah dalam hal pengambilan data yang dilakukan secara campuran antara langsung (offline) dan daring (online) melalui google form dikarenakan dalam masa pandemi covid-19 ini tidak memungkinkan dilakukan secara langsung. Sehingga kurangnya observasi dan interview untuk mengetahui tingkat pemahaman responden penelitian mengenai aitem pertanyaan yang diberikan dalam kuesioner yang dibagikan secara daring. Hal ini akan berpengaruh dalam pemahaman terhadap aitem-aitem yang ada pada alat ukur tersebut sehingga untuk penelitian selanjutnya akan lebih baik jika pengambilan data dapat dilakukan secara langsung (offline) agar peneliti dapat memantau tingkat pemahaman partisipan dalam mengisi kueisoner tersebut. Selain itu, sebaran jumlah orang tua yang berjenis kelamin laki-laki dan perempuan dalam penelitian ini tidak sebanding sehingga pada penelitian selanjutnya perlu dipertimbangkan jumlah laki-laki dan perempuan sebagai orang tua yang ikut serta dalam pengasuhan anak usia Sekolah Dasar. Hal ini mempertimbangkan bahwa stress dalam pengasuhan yang dirasakan oleh laki-laki dan perempuan memungkinkan adanya perbedaan karena adanya perbedaan sudut pandang antara laki-laki dan perempuan sehingga dapat berhubungan pula dengan strategi regulasi emosi yang digunakan oleh orang tua laki-laki dan perempuan.

Untuk penelitian selanjutnya, diharapkan dapat diteliti pengaruh dari regulasi emosi terhadap parenting stress serta sebaliknya sehingga dapat diperoleh gambaran faktor-faktor yang turut mempengaruhi pengasuhan anak.

\section{Daftar Pustaka}

Berry, J. O., \& Jones, W. H. (1995). The Parental Stress Scale : Initial Psychometric Evidence. Journal of Social and Personal Relationships, 12(3), 463-472.
Bornstein, M. (2002). Handbook of Parenting Volume 3: Being and Becoming A Parent. New Jersey: Lawrence Erlbaum Associates, Publishers.

Deater-Deckard, K. (2004). Parenting Stress. London: Yale University Press.

Del Giudice, M. (2014). Middle Childhood: An Evolutionary - Developmental Synthesis. Child Development Perspectives, 1-8.

Gross, J. J., \& John, O. P. (2003). Individual Differences in Two Emotion Regulation Processes: Implications for Affect, Relationships, and Well-Being. Journal of Personality and Social Psychology, 85(2), 348. doi: 10.1037/0022-3514.85.2.348.

Gross, J. J., \& Thompson, R. (2007). Emotion Regulation Conceptual. Handbook of Emotion Regulation (edited by James J. Gross, ed.). New York: Guilfors Publication.

Hu, X., Han, Z. R., Bai, L., \& Gao, M. M. (2019). The Mediating Role of Parenting Stress in The Relations Between Parental Emotion Regulation and Parenting Behaviors in Chinese Families of Children With Autism Spectrum Disorders: A Dyadic Analysis. Journal of Autism and Developmental Disorders, 49(10), 3983-3998.

Ikasari, A., \& Kristiana, I. F. (2018). Hubungan antara Regulasi Emosi dengan Stres Pengasuhan Ibu yang Memiliki Anak Cerebral Palsy. Empati, 6(4), 323-328.

Mardina, R. (2018). Kekerasan terhadap Anak dan Remaja. In InfoDatin: Pusat Data dan Informasi Kementrian Kesehatan Indonesia. Retrieved from http://www.kemkes.go.id/download.php?file $=$ download/pusdatin/infodatin/Kekerasanterhadap-anak.pdf

Moore, S. A., Zoellner, L. A., \& Mollenholt, N. (2008). Are Expressive Suppression and Cognitive Reappraisal Associated with Stress-Related Symptoms?. Behavior Research and Therapy, 46(9), 993-1000. doi: 10.1016/j.brat.2008.05.001 
Papalia, D. E., Olds, S. W., \& Feldman, R. D. (2004). Human Development. New York: McGraw-Hill.

Pinandita, V. (2020, 10 Januari). Kekerasan pada Anak Tak Menurun. Lokadata.id. Retrieved from website: https://lokadata.id/artikel/2020-kekerasanpada-anak-tak-menurun

Small, R. (2010). A Comparison of Parental SelfEfficacy, Parenting Satisfaction, and Other Factors between Single Mothers with and witout Children with Developmental Disabilities (Dissertation). Wayne State University. 